\title{
Provincial Governance in Africa: The Ghanaian Experience
}

\author{
By Joseph R.A. Ayee, Durban*
}

\section{Introduction $^{1}$}

There is growing interest in provincial governance, which has been manifested by the creation of states, regions and provinces in almost all African states (see Table 1). This interest is due to a number of reasons. First, provincial governance is an important component of decentralization globally because provinces or states or regions as they are called in the various countries depending on their constitutions and structure of government form the second tier of government immediately below the central government. The division of a country into provinces, states or regions is based on the principle of the functional units necessary in the process of decentralizing decision making powers of the central government either through political or administrative decentralization. Like local government units, provinces, states and regions are created for political, administrative, economic and social reasons ${ }^{2}$. In South Africa, for instance, provinces were created to either provide "racial minorities with opportunities to escape majority rule or, as [former South African President] Thabo Mbeki complained in 1995, allows the divisive mobilization of ethnic identities"3. Similarly, in Nigeria the creation of states is largely attributed to pressure by identities and communities for an equitable share of the national cake and a right to their "self-determination". 4

Secondly, the heads of provinces, states or regions known as premier or governor or minister wield enormous power because in most instances they are the representative of the head of state or head of government in their areas of jurisdiction. In addition, they have a

Joseph R.A. Ayee, Professor/Deputy Vice Chancellor, University of KwaZulu-Natal, Durban, South Africa. E-mail: Ayee@ukzn.ac.za.

1 This paper was originally presented at the $6^{\text {th }}$ National Annual Government Conference on "Provincial Governance and Development in South Africa Post 1994: Quo Vadis?", organized by the Democracy Development Programme (DDP) and held in Durban, South Africa from 14-15 October 2010.

See Brian Smith, Decentralization: The Territorial Dimension of the State, London 1985; Shabbir Cheema / Dennis Rondinelli, "From Government Decentralization to Decentralized Governance", in: G.S. Cheema / Dennis Rondinelli (eds.), Decentralizing Governance: Emerging Concepts and Practices, Washington DC 2007, pp. 1-14.

Steven Friedman / Caroline Kihato, "South Africa's Double Reform: Decentralization and the Transition from Apartheid", in: Philip Oxhorn / Joseph S. Tulchin / Andrew D. Selee (eds.), Decentralization, Democratic Governance, and Civil Society in Comparative Perspective - Africa, Asia and Latin America, Baltimore and London 2004, p. 180.

4 See Oghosa Osaghae, Crippled Giant: Nigeria Since Independence, London 1998; Egite Oyovbaire, Federalism in Nigeria, London 1985. 
lot of resources in the form of making appointments to certain government positions with which to buy patronage, which in some countries have exacerbated neopatrimonialism and corruption $^{5}$.

Thirdly, provincial governance encompasses big cities, all of them being either the national or state or provincial or regional capital. Examples are Cairo, Kinshasa, Lagos, Accra, Abuja, Dakar, Abidjan, Cape Town, Pretoria, Dar-es-Salaam, Nairobi and Kampala which have all experienced the surge of urbanization. Most of them have been designated as "metropolitan areas", that is, "cities with a very large urbanized core, together with adjacent urban and rural areas which have a high degree of economic and social integration with that core" ${ }^{\text {. }}$. It has been estimated that these cities make greater substantial contribution to the national economy than do small towns and rural areas. For instance, in Africa, Abidjan (Côte d'Ivore) and Nairobi (Kenya) constitute $18.1 \%$ and $5.2 \%$ of the populations of their countries but contribute $33.1 \%$ and $20.1 \%$ of national Gross National Product respectively ${ }^{7}$. Accordingly as provincial cities, they have emerged to become metropolitan government for a number of reasons:

(i) The growth of population and the expansion of economic activity appear to cause urban municipalities to reach a saturation point. Economic growth may be retarded because one city or municipality has no say in the development of neighbouring localities. The general complaint is that central cities and towns are denied reasonable space for essential development;

(ii) For certain services and infrastructural investments, individual municipalities within large metropolitan areas no longer appear to have jurisdiction over the optimal area. Many services, such as sanitation, public transport and security should be provided for the area as whole;

Land-use planning can only be provided in a coordinated way if the area includes the integrated economic and social metropolitan area as a whole; and

(iii) The need informed by a more regionally-based government to redistribute resources and services from richer to poorer areas ${ }^{8}$.

Against this backdrop, this paper examines provincial or regional governance in Ghana based on the following indicators: (I) The political economy of the creation of regions; (II)

See Catherine Boone, Decentralization as a Political Strategy in West Africa, Comparative Political Studies 36, 4 (2003), pp. 355-380; Fumihiko Saito, Introduction, in: Fumihiko Saito (ed.), Foundations for Local Governance: Decentralization in Comparative Perspective, Leipzig 2008, pp. 1-15.

United Nations, World Urbanization Prospects: The 2001 Revision, New York 2002, p. 134.

Richard Stren / Robert Cameron, Guest Editor's Preface: Metropolitan Governance Reform: An Introduction, Public Administration and Development, 25 (2005), pp. 275-284.

8 See Stren / Cameron, note 7, p. 276; Leslie J. Sharpe (ed.), The Government of World Cities: The Future of the Metro Model, Chichester 1995; George R. Stephens / Nick Wikstrom, Metropolitan Government and Governance: Theoretical Perspectives, Empirical Analysis and the Future, New York 2000. 
Constitutional authority; (III) Electoral process; (IV) Range of expenditure and management responsibilities devolved; (V) Authority and competence of staff; (VI) Regional governance and party politics 9 .

Table 1: Some Countries in Africa with Provincial Administration

\begin{tabular}{|l|l|l|l|}
\hline Country & Political System & $\begin{array}{l}\text { Type of } \\
\text { State }\end{array}$ & Province/State/Region \\
\hline Algeria & Presidential & Unitary & 48 Wilaya (Provinces) \\
\hline Cameroon & Presidential & Unitary & 10 Regions \\
\hline $\begin{array}{l}\text { Arab Rep. of } \\
\text { Egypt }\end{array}$ & Presidential & Unitary & 26 Muhafasats (Provinces) \\
\hline Cote d'Ivoire & Presidential & Unitary & 19 Regions \\
\hline Ghana & Quasi-Presidential & Unitary & 10 Regions \\
\hline Kenya & Presidential & Unitary & $\begin{array}{l}8 \text { Provinces including the city of } \\
\text { Nairobi }\end{array}$ \\
\hline Madagascar & Presidential & Unitary & 22 Faritany (Regions) \\
\hline Mali & Presidential & Unitary & 8 Regions \\
\hline Morocco & Constitutional Monarchy & Unitary & 16 Regions \& 49 Provinces \\
\hline Mozambique & Presidential & Unitary & 10 Provinces \\
\hline Niger & Semi-presidential & Unitary & 8 Regions including Niamey \\
\hline Nigeria & Presidential & Federal & 36 States \\
\hline Senegal & Presidential & Unitary & 11 Regions \\
\hline South Africa & Mixed parliamentary and & Federal & 9 Provinces \\
\hline presidential & Presidential & Unitary & 6 Regions \\
\hline Tunisia & Presidential & Unitary & 24 Governorates (Regions) \\
\hline
\end{tabular}

Source: World Bank, Decentralization and Local Democracy in the World. First Global Report by United Cities and Local Governments, Washington, DC 2008, pp. 26-27.

\section{Regional Governance and Decentralization in Ghana}

Regional administration has been part of the decentralization process in Ghana since independence. The current decentralization process in Ghana has established multiple layers of subnational authorities. It has a four-level structure of government, divided into the following levels:

9

Pranab Bardhan / Dilip Mookherjee, The Rise of Local Governments: An Overview, in: Pranab Bardhan / Dilip Mookherjee (eds) Decentralization and Local Governance in Developing Countries: A Comparative Perspective, Cambridge, MA, 2006, pp. 1-20. 
1. National government (including line ministries and deconcentrated entities);

2. Regional Coordinating Councils (RCCs), which are the regional governance institutions;

3. Metropolitan, Municipal and District Assemblies (MMDAs); and

4. Sub-district structures: Urban, Zonal and Town Councils, and Unit Committees (see Figure 1).

The core units of decentralized governance, representing "local government", are the MMDAs. Whether a locality is governed by a Metropolitan, Municipal, or District Assembly depends upon population size: Metropolitan Assemblies existing only in the country's six largest cities (Accra, Cape Coast, Kumasi, Sekondi-Takoradi, Tema, and Tamale), Municipal Assemblies in the next 40 largest cities, and District Assemblies throughout the remainder of the country. Each of these forms has its own sub-district structures (see Figure $1)$.

The Political Economy of Creation of Regions in Ghana: Ghana is a unitary republic with a constitution based on the model of the United States of America. The 1992 Constitution stipulates that the state is based on a presidential system of government, with a separately elected legislature. There are 10 regions in Ghana (see Table 2). Each of them is further divided into districts making a total of 170 districts (see Table 3).

The creation of regions shows the incentives governments had for creating them. Ghana before independence on March 6, 1957 had five administrative provinces, namely, Eastern, Western, Ashanti, Northern Territories and Trans-Volta Togoland. This was the colonial provincial deconcentrated administrative system whereby the governor gave instructions to provincial and district commissioners - field agents - whose main responsibilities were to maintain law and order and collect revenues ${ }^{10}$. On the heels of independence, there was the need to transform the provincial administrative structure bequeathed by the British and reorient it to assume the role of socio-economic accelerator. This transformation was necessary, more so, to fall in line with the great emphasis placed on national planning by Kwame Nkrumah's Convention People's Party government for a "projected prosperous Ghana"11. Region management, therefore, had to assume a new dimension - a bridge in regionalnational integration and furthermore a link between the central government and local government units. This was felt to be necessary if each citizen was to make a "maximum stration, XL, 1, (January-March 1994), pp. 47-56. 
Figure 1: Ghana's Decentralization Structure

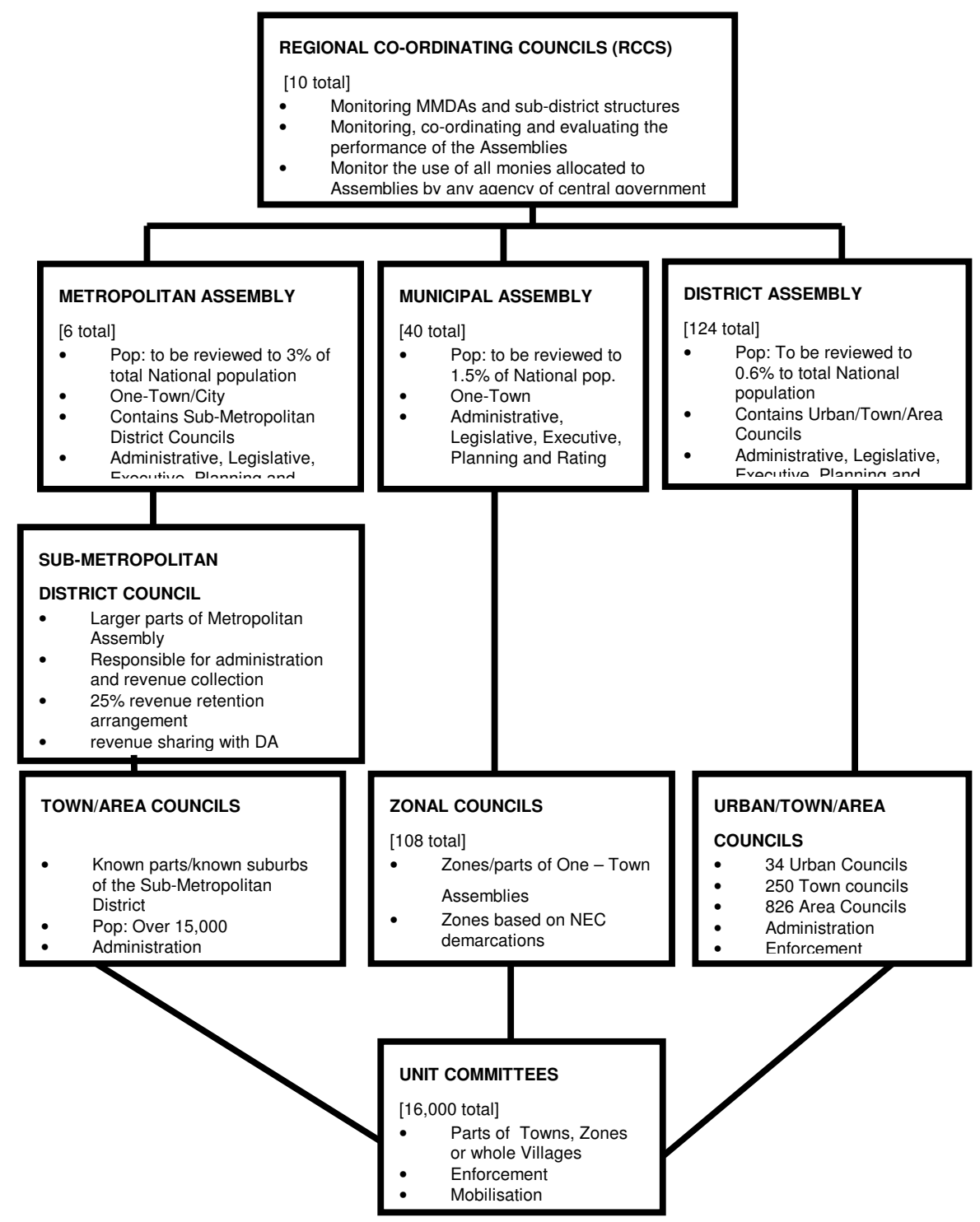


contribution to the national economy"12. Accordingly, the five provinces with renamed regions and the Northern Territories and Trans-Volta Togoland rechristened Northern and Volta Regions.

The CPP government created four more regions before it was overthrown by the military junta of the National Liberation Council on 24 February 1966. They are the Brong Ahafo Region, Greater Accra Region, Central Region and Upper Region which was hived off from the Northern Region. The creation of the Brong Ahafo region was the outcome of a long period of agitation by the Ahafo and Brong people who were not happy to be part of the restored Asante Confederacy in 1935 and the "massive support they gave the CPP in the 1956 elections" as well as the desire of the CPP government to curb the power and prestige of the Asantehene, the influential and all-power paramount chief of the Asante Kingdom $^{13}$. The Brong Ahafo Region Act (Act 18) of 1959 divided the Ashanti Region into two parts. The western part of Ashanti together with the southern section of the Northern Region below the Volta River became the Brong Ahafo Region to incorporate the Brong and Ahafo people; while the eastern sector was retained as the Ashanti Region. ${ }^{14}$

Before the coming into force of the Republican Constitution on 1 July 1960, the CPP government decided the country should be divided into "more effective administrative units". By the Regions of Ghana Act (CA 11) of 1 July 1960, two additional regions were created. The Northern Region was divided into Northern and Upper Regions while the Western Region was divided into Western and Central Regions. The splitting up of the Northern region was justified on the grounds that it was a very wide underdeveloped one ${ }^{15}$. In 1965, the Greater Accra Region was carved out of the Eastern Region to become Ghana's ninth region not only to facilitate smooth and efficient administration of the area but also to satisfy the demands for a region which was led by the paramount chiefs of Ga and $\mathrm{La}^{16}$.

Ghana's tenth region, the Upper West Region was created out of the Upper Region by The Regions of Ghana (Amendment Law), PNDC Law 41 of 14 January 1983 by Rawlings' Provisional National Defence Council (PNDC). The agitations for a separate region began as far back as 1960 and the response of successive governments was not encouraging. The agitations for a separate Upper West Region by chiefs and the youth were based on the following grounds:

Kwame Nkrumah, Speech delivered at the launching of the Seven Year Development Plan, March. Accra 1964, pp. 2-3.

Dennis Austin, Politics in Ghana: 1946-1960, London 1964, pp. 23-28; Adu Boahen, Ghana: Evolution and Change in the Nineteenth and Twentieth Century, London 1975, pp. 7-9. See Ayee, note 11, p. 52; Raymond B. Bening, The Regional Boundaries of Ghana, 1874-1973, Research Review, 9, 1 (1973), pp. 35-48. 
- That the underdevelopment of the Upper West area of the Upper Region stemmed from the over-concentration of power and development in and immediately around Bolgatanga, the regional capital;

- That the Upper West area possessed enormous agricultural resources due to the rich diversity of her soils;

- That from statistical evidence, the Upper West area provided the largest number of students to educational establishments in the Northern and Upper Regions and yet no single polytechnic, technical school, post-secondary, sixth form or farm management institute existed in the area; and

- That the Upper West area lacked telegraph and telephone facilities, while feeder and trunk road networks were in a poor state ${ }^{17}$.

Table 2: Ghana's 10 Regions

\begin{tabular}{|c|c|c|}
\hline Name of Region & Government & Year of Creation \\
\hline Ashanti & Convention People's Party & 1957 \\
\hline Eastern & Convention People's Party & 1957 \\
\hline Northern & Convention People's Party & 1957 \\
\hline Volta & Convention People's Party & 1957 \\
\hline Western & Convention People's Party & 1957 \\
\hline Brong Ahafo & Convention People's Party & 1959 \\
\hline Central & Convention People's Party & 1960 \\
\hline Upper & Convention People's Party & 1960 \\
\hline Greater Accra & Convention People's Party & 1964 \\
\hline Upper East & $\begin{array}{c}\text { Provisional National Defence } \\
\text { Council }\end{array}$ \\
\hline
\end{tabular}

The fact that it was Rawlings' PNDC government which created the Upper West Region accounts for the massive votes which Rawlings' party, the National Democratic Congress (NDC) has received from elections held in 1992, 1996, 2000 and $2004^{18}$.

These grievances were contained in the following letters: (i) From the Wa-Naa Sidiki Bome II and other chiefs of June 12, 1970 to the President of the Second Republic in File No. SCR 12/67 (Castle, Osu); (ii) From the Wa-Naa Sidiki Bome III and other chiefs, July 28, 1976 to the head of state, General I.K. Acheampong in File No. SCR 19/75 (Castle, Osu); (iii) From the Upper West Student Union (UWESU), March 20, 1980 to the President of the Third Republic, Dr Hilla Limann, in File No. SCR 47/93 (Castle, Osu); (iv) From the Wa-Naa, Mimori Bondiri II and others, March 1980 to the President of the Third Republic in File No. SCR 48/94 (Castle, Osu). 
In Ghana today, there are still agitations for the creation of more regions. For instance, the people in the northern part of the Volta Region and Northern Region are agitating for separate regions. A region to be called Savannah is being proposed for the one to be carved out of the Northern Region.

Table 3: Creation of districts from 1988/89 to 2008

\begin{tabular}{|l|l|l|l|l|l|l|l|}
\hline Region & $\begin{array}{l}\text { No. of } \\
\text { districts } \\
\text { before } \\
\mathbf{1 9 8 8 / 8 9}\end{array}$ & $\begin{array}{l}\text { No. of } \\
\text { districts } \\
\text { created in } \\
\mathbf{1 9 8 8 / 8 9}\end{array}$ & $\begin{array}{l}\text { Total no. } \\
\text { of } \\
\text { districts } \\
\text { before } \\
\mathbf{2 0 0 4}\end{array}$ & $\begin{array}{l}\text { Districts } \\
\text { created, } \\
\text { Election } \\
\text { Year 2004 }\end{array}$ & $\begin{array}{l}\text { No. of } \\
\text { districts } \\
\text { in 2007 }\end{array}$ & $\begin{array}{l}\text { Districts } \\
\text { created, } \\
\text { Election } \\
\text { Year } \\
\mathbf{2 0 0 8}\end{array}$ & $\begin{array}{l}\text { No of } \\
\text { districts } \\
\text { in 2008 }\end{array}$ \\
\hline Ashanti & 10 & 8 & 18 & 3 & 21 & 6 & 27 \\
\hline Brong Ahafo & 8 & 5 & 13 & 6 & 19 & 3 & 22 \\
\hline Central & 8 & 4 & 12 & 1 & 13 & 4 & 17 \\
\hline Eastern & 9 & 6 & 15 & 2 & 17 & 4 & 21 \\
\hline Greater Accra & 3 & 2 & 5 & 1 & 6 & 4 & 10 \\
\hline Northern & 7 & 6 & 13 & 8 & 21 & 2 & 23 \\
\hline Upper East* & 4 & 2 & 6 & 2 & 8 & 1 & 9 \\
\hline Upper West* & 3 & 2 & 5 & - & 5 & 4 & 9 \\
\hline Volta & 8 & 4 & 12 & 3 & 15 & 3 & 18 \\
\hline Western & 5 & 6 & 11 & 2 & 13 & 4 & 17 \\
\hline Total & 65 & 45 & 110 & 28 & 138 & 32 & 170 \\
\hline
\end{tabular}

* Before January 1983, the Upper East and Upper West regions were collectively known as Upper Region. In all, the Upper Region had 7 districts, 4 from the Upper East area and the remaining 3 from the Upper West area.

Constitutional authority: Since independence all Ghanaian constitutions have enshrined clauses on regional governance. In Chapter 2, "The Territories of Ghana", in the current 1992 Constitution, for instance, the President of the Republic has the power through a constitutional instrument to create a new region, alter the boundaries of a region or provide for the merger of two regions or more. However, the President's power is subject to demands in the form of a petition and on the advice of the Council of State a Commission of Inquiry to inquire into the demands or the need to create, alter or merge. If the Commission of Inquiry finds that there is the need and a substantial demand for either creation, alteration or merger, the matter should be decided at a referendum. At the referendum, the

Ghana: Politics of the 2000 Elections (Thematic and Constituency Studies), (Volumes 1 \& 2), Accra, 2001; Joseph R.A. Ayee, The 2000 General Elections and Presidential Run-off in Ghana: An Overview, Democratization, 9, 2, (Summer 2002), pp. 148-174; Joseph R.A. Ayee, 'Voting Patterns in Ghana's 2004 Elections', in Friedrich Ebert Foundation (ed.), Elections 2004: Ghana Parliamentary and Presidential Elections, Accra 2005, pp. 82-100. 
creation or the altering of a region should be determined by at least $50 \%$ of the people entitled to cast their votes, and of the votes cast at least $80 \%$ should be cast in favour of the issue. Similarly, for referendum involving the merger of two or more regions, the issue will be determined only if at least $60 \%$ of the voters voted. Given the constitutional provisions, it is clear that the creation of regions is a sensitive issue which cannot be politicized or granted on frivolous demands.

Furthermore, Chapter 20 (255) of the Constitution, "Decentralization and Local Government" makes provision for the establishment of Regional Coordinating Council (RCC), that is, the regional administration, in each region. As we will see later, in spite of the recognition of regional governance in the Constitution, the regional structure does not have independent authority mainly because Ghana is not only a unitary state but also the regional structure operates as an appendage of the national government with no legislative and rating powers and personnel of its own. It is instructive to note that it is the President who appoints the Regional Minister with the prior approval of Parliament. The Minister represents the President in the region and is "responsible for coordination and direction of administrative machinery in the region" 19 . The President also appoints a Deputy Regional Minister in consultation with the Regional Minister and with the prior approval of Parliament. The RCCs are chaired by a Regional Minister (a presidential appointee), and led administratively by Regional Coordinating Directors (RCDs) and Regional Planning Coordinating Units (RPCUs).

Electoral process: None of the officials of the RCC is elected directly. The RCC brings together key actors in Ghana's decentralization matrix. It consists of the following: (i) the Regional Minister and his deputy of deputies, who are appointed by the President; (ii) the District Chief Executive from each District in the Region, who are appointed by the President with the prior approval of not less than two-thirds majority of the members of the Metropolitan, Municipal or District Assembly (MMDA) present and voting at the meeting (iii) the Presiding Member from each District in the Region, who is elected by the MMDA from among its members; (iv) Two chiefs from the Regional House of Chiefs elected by them at a meeting of the House; (v) the regional heads of the decentralized ministries in the region without the right to vote; (vii) The Regional Coordinating Director (RCD), a career civil servant and head of the regional administration as secretary. Consequently, apart from the two representatives from the Regional House of Chiefs who are elected, the other members of RCC are there as ex-officio members.

Political parties are debarred from participating in the affairs of the RCC. This is because of the constitutional provision of a non-partisan decentralized structure: ${ }^{20}$ 
A candidate seeking election to a District Assembly or any lower local government unit shall present himself to the electorate as an individual, and shall not use any symbol associated with any political party ... A political party shall not endorse, sponsor, offer a platform to or in any way campaign for or against a candidate seeking election to a District Assembly or any lower local government unit.

The non-partisanship side of decentralization has been a vexed one. While some think that it is an anomaly to have such a system in a partisan national system of government, others have the view that it is all right given that development at the local level does not need to be polarized along partisan lines. In practice, however, it is difficult to practise the constitutional provision because there have been serious infractions as political parties support candidates in all the local government elections held in 1996, 2002 and $2006^{21}$. The December 2010 local government elections also followed a similar pattern.

From the foregoing, the regional structure is an administrative and technical body and therefore its membership remains largely so. The mix of devolved, deconcentrated, and delegated authorities has made aligning the RCC into the decentralization process somewhat contradictory.

Range of expenditure and management responsibilities devolved to the RCCs: The Regional Coordinating Councils (RCCs) are entities with delegated authority to coordinate and harmonize district-level development interventions. They serve as an intermediate coordinating and monitoring link between the central government and the districts. Specifically, the RCCs: (i) monitor, coordinate and evaluate the performance of MMDAs in the region; (ii) monitor the use of all monies allocated to the MMDAs by any agency of the central government; and (iii) generally review and coordinate all public services in the region $^{22}$. There is no constitutional provision for the funding of the RCCs even though they are not rating bodies. They do not provide services to the region. They are located within MMDAs, which are mandated to provide services and therefore have not only taxing powers but also enjoy a share of the constitutionally established District Assembly Common Fund (DACF) into which not less than $5 \%$ of all government revenues is lodged for disbursement to the 170 districts based on a revenue sharing formula designed by the Administrator of the Fund solely for development.

One of the functions of the RCCs is regional development. Accordingly, all RCCs had set up Regional Planning Coordinating Units (RPCUs) to formulate regional development policy, coordinate and harmonize district level development interventions, monitor implementation activities of the MMDAs; develop implementation monitoring indicators, and report to the centre. However, this function has not been properly performed because the

Joseph R.A. Ayee, Decentralization and Governance in Ghana, Regional Development Dialogue, 29, 2 (Autumn 2008), pp. 34-54;

22

Republic of Ghana, note 19, pp. 141-142; Republic of Ghana, Local Government Act, Act 462, Accra 1993, Chapter 20. 
process of aligning RCCs, RCDs and RPCUs into the decentralization process has been slow and confusing. This is due in part to the contradictory nature of the laws and also due to lack of capacity for these institutions to occupy the space provided under the law. Moreover, many of the functions to be delegated to them are still being performed by the regional offices of the line Ministries Departments and Agencies (MDAs). The latter continue to obtain the needed funding from central government, through the medium term expenditure framework (MTEF) budget arrangement to perpetuate their role as regional policy makers and coordinators but on sectoral levels.

This notwithstanding, some progress has been made over the past three years since the Decentralization Secretariat of the Ministry of Local Government and Rural Development have provided needed skills and capacity for the RPCUs in much of the Southern regions with Canadian International Development Agency (CIDA) supporting RPCUs in the three Northern regions.

The RCCs do not have autonomy in hiring, firing and paying of personnel because they do not have a staff of their own as the staff are civil servants. In spite of the creation of a Local Government Service with the passage of the Local Government Service Act, Act 656 of 2003 to consist of persons holding non-elected public office in the RCCs, the MMDAs and their sub-district structures, efforts to integrate staff into the structures of the decentralized units have not materialized.

The RCCs are financed by the central government and disbursement from the District Assembly Common Fund. The factor of contingency which attracts $1 \%$ of the revenue sharing formula of the DACF is used to finance the RCCs. There is little empirical evidence on how much funds are under the disposal of the RCCs. The impression created by officials of the RCCs is that they are cash-trapped as disbursement is not only erratic but also sharply reduced every year.

Authority and competence of staff: The authority and competence of the staff of the RCCs are not in doubt. In fact, their staff are more competent than those belonging to MMDAs. Given that majority of its members have high administrative and technical skills, they have the capacity to monitor and evaluate the performance of the MMDAs. This notwithstanding, the fact that they are non-elective bodies consisting of ex-officio members, has not shifted the balance of actual control rights from central bureaucrats to elected officials. In addition, decisions taken by the RCC largely reflect the political character of its headship, that is, the Regional Minister and his/her deputies.

Even though the RCCs play a rather secondary role in the system of local government in Ghana, they are very powerful in practice, especially when there has been no agreement on their "coordinating and monitoring" functions. They seem to direct and control the activities of the MMDAs in practice to ensure that they operate within legislated limits. This is a way of guaranteeing some measure of supervision from the centre. In addition, sometimes the power to approve or reject the bye-laws of the MMDAs is delegated to the RCCs by the Minister of Local Government and Rural Development. Furthermore, they 
have become channels or forums for some aggrieved citizens to communicate their priorities and concerns to their MMDAs ${ }^{23}$.

Regional governance and party politics: Even though regional and local governance are non-partisan in theory, in practice, however, they are not. At the regional level, the Regional Minister and his deputies are dye-in-wool officials of the party in power. They are overly partisan. As already noted, the Regional Minister and his deputies are appointed by the President while the Regional Minister is the representative of the President in the region. Given his high profile in the party in the region, the Regional Minister is involved in the selection of chief executives of the MMDAs and the one-third government nominees in the MMDAs from party lists drawn. Since he has a hand in their appointments, the chief executives become loyal to the Regional Minister in a patron-client relationship.

In addition, most decisions taken by the Regional Ministers have tended to favour their party in the regions. As chairman of the Regional Security Committee (RegSec), there are instances where Regional Ministers had used their positions to support one faction against the other because the faction they supported was ally of the ruling government. This stance has resulted in either the perpetuation or escalation of the conflicts. There are also instances where the Regional Ministers had disagreed with the advice of the Regional Police Commanders in security matters in the regions and resulted in personal conflict between them. For instance, in 2009, there was personal conflict between the Regional Minister and the Regional Police Commander, which led to the removal of the Police Commander to the national headquarters at the instance of Regional Minister ${ }^{24}$. The neutrality of the RegSec in regional conflicts seems therefore to be questionable in this matter.

\section{Conclusion}

This paper has shown that regional governance in Ghana is an extension of the central government. The constitutional provisions of Ghana being a unitary state and regional governance regarded as an additional roadblock to genuine decentralization to the grassroots have led to the regional structures being stripped off from performing legislative and rating roles. They have also not been given specific responsibilities apart from the general ill-defined and ambiguous ones of monitoring and coordinating. In spite of its secondary role, regional governance is still very powerful in serving as a form of patronage and complementary support for the party in power. This is observation is similar to the South African context, where it has been noted that provincial and local governments create considerable scope for patronage and nepotism, and that they have provided unaccountable local

Joseph R.A. Ayee, Reinforcing Democratic Governance in Ghana: Public Servants and Partisan Politics, paper presented at the 2009 Annual Lecture of the Public Services Commission on the theme "Public Servants under Constitutional Governance" held at the British Council Hall on May 20, 2009. 
elites with opportunities to use public institutions to entrench private power. Accordingly, far from providing citizens with representative vehicles, they have diminished democratic possibilities by entrenching local elites and thereby supporting the party in power, that is, the African National Congress (ANC) ${ }^{25}$.

It is also instructive to note that it is not only the Ghanaian regions which are largely subordinate to the centre. In South Africa, for instance, the nine provinces are subservient to the central government. The 1996 South African Constitution allows the central government to take over the powers or functions of the provinces if a province "cannot or does not fulfill an executive obligation in terms of legislation or the Constitution" or an action is needed to prevent a province "from taking unreasonable action that is prejudicial to the interests of another province or to the country as a whole" ${ }^{, 6}$. In addition, the provinces as in the Ghanaian case have limited revenue raising powers. Apart from the right to raise funds from gambling, for example, they are dependent on block grants from the central government. Even though the provinces have been given discretionary power to use the block grants as they wish, in practice, however the freedom to use them is eroded as the central government through concurrency has in some cases determined spending patterns by decreeing norms and standards (for instance, agreed wage rates are binding on the provinces or insistence on teacher-pupil ratios in schools $)^{27}$. 